\title{
PENGENALAN POTENSI DAN MITIGASI BENCANA BAGI KADER DI KAWASAN WISATA PANTAI SELATAN MALANG
}

\author{
Kristianto Dwi Nugroho ${ }^{1}$, Ucip Sucipto ${ }^{2}$ \\ 1,2Pengajar di Program Studi S1 Keperawatan STIKes Panti Waluya Malang \\ Jalan Yulius Usman No.62, Malang 65117, telepon: 0341-369003 \\ e-mail: kristianto.nugroho77@yahoo.co.id
}

\begin{abstract}
ABSTRAK
Kegiatan Program Kemitraan Masyarakat "Pelatihan Bantuan Hidup Dasar Bagi Kader Di Kawasan Wisata Pantai Selatan Malang" diawali dengan pengkajian awal terhadap keadaaan di lapangan. Pengkajian awal didapatkan permasalahan bahwa semakin bertambah terkenalnya objek wisata di Kawasan pantai selatan Malang, maka jumlah wisatawan akan semakin banyak. Tetapi disisi lain belum masih kurangnya pengetahuan warga dan kader masyarakat dalam memberikan pertolongan pertama pada keadaan gawat darurat. Permasalahan lain yang dihadapi adalah resiko bencana yang cukup besar. Mengingat pantai selatan memiliki resiko bencana seperti banjir, tanah longsor dan bencana tsunami. Semakin bertambahnya wisatawan yang dapat pada Kawasan wisata juga meningkatkan jumlah tenggelam di sekitar Kawasan wisata. Edukasi kepada kader dan masyarakat untuk meningkatkan kesiapsiagaan dalam keadaan gawat darurat. Kegiatan penanganan gawat darurat diawali dengan pelatihan kepada kader dan masyarakat mengenai penanggulanan keadaan gawat darurat. Pelatihan berupa bantuan hidup dasar dan penyadaran masyarakat mengenai resiko bencana yang bisa mengancam pada kawasan wisata pantai selatan malang. Bentuk kegiatan berupa pelatihan penaganan gawat darurat pada masyarakat awam. Selain itu, pelatihan pertolongan pertama pada pasien tenggelam. Bentuk penyadaran masyarakat mengenai potensi bencana yang ada. Dengan adanya edukasi dan pengingkatan kesadaran masyarakat mengenai potensi bencana, diharapkan pada akhirnya dapat meningkatkan kualitas hidup masyarakat.
\end{abstract}

\section{Kata Kunci : Pertolongan Pertama, Gawat Darurat, Pantai, Wisata}

\begin{abstract}
The activity of the Community Partnership Program "Basic Life Support Training for Cadres in Malang South Coast Tourism Area" begins with a preliminary assessment of the situation on the ground. Preliminary assessment found that the more popular tourist attractions in the southern coast of Malang, the more tourists there will be. But on the other hand there is still a lack of knowledge of residents and community cadres in providing first aid in emergency situations. Another problem faced is the considerable risk of disaster. Given the south coast has the risk of disasters such as floods, landslides and tsunami disasters. The increasing number of tourists who get to the tourist area also increases the number of drowning around the tourist area. Educate cadres and the community to increase preparedness in emergencies. Emergency management activities begin with training of cadres and the community on handling emergency situations. Training in the form of basic life assistance and public awareness about the risk of disasters that could threaten the tourist area of Malang's south coast. The form of activity is in the form of emergency care training for the general public. In addition, first aid training in drowned patients. Form of public awareness about the potential for existing disasters. By educating and increasing public awareness about potential disasters, it is hoped that in the end it can improve the quality of life of the community.
\end{abstract}

\section{Key Words: First Aid, Emergency, Beach, Travel}




\section{PENDAHULUAN}

Manajemen bencana atau yang sering disebut dengan penanggulangan bencana merupakan proses yang dinamis, terpadu dan berkelanjutan yang meliputi kegiatan pencegahan, mitigasi dan kesiapsiagaan, tanggap darurat, evakuasi, rehabilitasi dan pembangunan kembali (Idup, Ilayah, \& Encana, 2004). Sedangkan mitigasi adalah tindakan untuk mengurangi potensi dampak negatif dari suatu bencana. Mitigasi bencana meliputi pengumpulan data dan analisis data bencana dalam rangka usaha memperkecil tingkat kerentanan dan bahaya suatu bencana (Jokowinarno, 2011).

Desa Sumber Bening terletak di Kecamatan Bantur, Kabupaten Malang, Jawa Timur yang memiliki penduduk lebih dari 726 jiwa per kilometer persegi (Provinsi Jawa Timur, 2018). Wilayahnya dikelilingi beberapa pantai selatan Malang seperti Pantai Balekambang, Pantai Rowo Gedang dan Pantai Merak. Deretan pantai tersebut berbatasan langsung dengan Samudra Indonesia yang tentunya memiliki ombak dan gelombang pasang yang tinggi.

Ombak dan gelombang tinggi merupakan suatu ancaman nyata karena bisa menyebabkan tsunami, gempa bumi dan longsor. Beberapa keadaan darurat yang mungkin saja bisa terjadi seperti kecelakaan, tenggelam, patah tulang sampai dengan serangan jantung (Holly, Swanson, Cachia, Beasant, \& Laird, 2017).

Desa Sumber Bening merupakan desa yang memiliki potensi wisata cukup baik karena wilayahnya yang berada di deretan Pantai Selatan Malang. Wisata Pantai yang relatif baru menjadikan peningkatan jumlah wisatawan di kawasan tersebut. Pertambahan jumlah wisatawan memiliki dampak yang positif terhadap masyarakat sekitar. Dari segi perekonomian dapat meningkatkan taraf hidup masyarakat sekitar. Masyarakat memiliki pendapatan tambahan melalui jualan makanan, jasa dan oleh-oleh. Namun di sisi lain perlu juga diperhatikan dampak negatifnya dengan bertambahnya jumlah wisatawan tentunya akan meningkatkan resiko terjadinya keadaan darurat seperti tenggelam, patah tulang, serangan jantung bahkan bencana alam. Ancaman bencana alam yang mungkin terjadi yaitu tsunami, gempa bumi dan longsor. Potensi bencana yang mungkin terjadi ternyata belum diimbangi oleh kesadaran masyarakat di Desa Sumber Bening. Rendahnya kesadaran tersebut dibuktikan dengan dilakukannya pengkajian pengetahuan potensi bencana, sebagian responden belum mengetahui (Dariyo, 2004).

Rendahnya kesadaran masyarakat mengenai potensi bencana yang bisa muncul, dapat dilihat dari profil pendidikan di masyarakat Sumber Bening yang sebagian besar berpendidikan rendah. Dan dari segi ekonomi pun sebagian masyarakat Sumber Bening memiliki ekonomi yang rendah (Sunarto, Marfai, \& Mardiatno, 2014). Guna meningkatkan kesejahteraan penduduk, beberapa upaya telah dilakukan oleh Pemerintah Kabupaten yaitu menjadikan desa Sumber Bening sebagai desa wisata. Diharapkan masyarakat dapat meningkatkan derajat ekonomi dan kemandirian. Pengembangan ekonomi seharusnya di imbangi dengan 
pengembangan pengetahuan masyarakat akan bencana yang bisa muncul suatu waktu. Sehingga jika terjadi bencana, ekonomi masyarakat tidak terganggu dan pemahaman masyarakat akan kesehatan khususnya kondisi kegawatdaruratan juga meningkat. Diharapkan dengan dilakukan pengembangan pengetahuan melalui mitigasi bencana menjadikan Desa Sumber Bening menjadi kawasan yang aman dan ramah bagi wisatawan.

Berikut adalah justifikasi permasalahan yang dikelola dalam program pengembangan masyarakat adalah meningkatnya jumlah wisatawan di daerah desa Sumber Bening sehingga diperlukan kesiapan masyarakat dalam penanganan kejadian gawat darurat.. Kurangnya kesadaran masyarakat mengenai pertolongan pertama dan bantuan hidup dasar. Selain itu, kurangnya pengetahuan mengenai potensi bencana dan prosedur evakuasi yang tepat.

Solusi dalam upaya penyelesaian masalah dengan cara pemberdayaan masyarakat di desa Sumber Bening, Kecamatan Bantur, Kabupaten Malang antara lain: (1) Memberikan penyuluhan mengenai potensi bencana terhadap peningkatan jumlah wisatawan di desa Sumber Bening, (2) Memberikan penyuluhan kepada kader dan masyarakat mengenai potensi bencana yang ada di desa Sumber Bening, (3) Memberikan penyuluhan tentang cara dan prosedur evakuasi yang tepat di desa Sumber Bening, (4) Memberikan pelatihan bantuan hidup dasar pada warga dan kader di desa Sumber Bening, (5) Memberikan pertolongan pertama pada warga dan kader di desa Sumber Bening

\section{METODE}

Metode pengabdian masyarakat yang dilakukan berupa penyuluhan dan praktik langsung. Alat yang digunakan berupa PowerPoint, LCD, Poster. Selain itu metode yang diberikan berupa pembuatan jalur evakuasi langsung dengan partisipan seluruh kader di saerah wisata Pantai Selatan, Desa Sumber Bening, Kecamatan Bantur, Kabupaten Malang.

\section{TAHAP PELAKSANAAN}

Pemberian pendidikan kebencanaan pada seluruh kader desa Sumber Bening, pendidikan kebencanaan berupa:

a. Identifikasi mengenai potensi bencana yang disadari oleh seluruh kader

b. Pemaparan potensi bencana yang mungkin terjadi di lingkungan, meliputi bencana gunung berapi, tanah longsor, gempa bumi, kebakaran hutan, angina dan debu vulkanik

c. Menjelaskan secara singkat mengenai potensi bencana yang mungkin terjadi dengan Bahasa dan pilihan kata yang sederhana

Bentuk pengabdian masyarakat

a. Penyuluhan mengenai potensi bencana yang diharapkan meningkatkan kesadaran masyarakat secara keseluruhan

b. Penyuluhan prosedur evakuasi saat bencana diharapkan prosedur evakuasi yang tepat dapat berjalan dengan baik dan efisien

c. Pendidikan kegawatdaruratan berupa bantuan hidup dasar diharapakan meningkatkan pengetahuan masyarakat mengenai pertolongan pada kasus henti jantung 
d. Pembuatan jalur evakuasi diharapkn kader dapat memandu masyarakat mengenai jalur evakuasi yang aman jika terjadi bencana

\section{HASIL dan PEMBAHASAN}

Kegiatan pengabdian masyarakat yang berjudul "Pengenalan Potensi Dan Mitigasi Bencana Bagi Kader Di Kawasan Wisata Pantai Selatan Malang” di tujukan untuk kader khususnya di desa Sumber Bening, Kecamatan Bantur, Kabupaten Malang. Tujuan dilakukan kegiatan ini untuk meningkatkan pengtahuan dan kesadaran masyarakat terhadap potensi bencana yang muncul melalui penyuluhan mitigasi bencana.

Kegiatan yang dilakukan pemberian pendidikan mengenai potensi bencana di sekitar pantai. Tujuannya pengenalan potensi bencana di kawasan wisata pantai. Hasil yang didapatkan seluruh peserta kegiatan aktif dalam kegiatan pengenalan potensi bencana.

Kegiatan selanjutnya penyuluhan mengenai prosedur evakuasi saat bencana. Tujuannya pengenalan prosedur dan evakuasi warga dan kader di kawasan wisata pantai selatan. Hasil yang dicapai seluruh peserta aktif dalam kegiatan pengenalan prosedur evakuasi kepada kader dan warga dalam menyelamatkan diri saat bencana.

Selanjutnya memberikan pendidikan kegawatdaruratan berupa bantuan hidup dasar. Tujuannya untuk meningkatkan pengetahuan dan kemampuan masyarakat khususnya anggota karang taruna untuk menolong penderita henti jantung. Hasil yang dicapai seluruh anggota karang taruna aktif terlibat dalam menolong penderita henti jantung. Kegiatan yang terakhir adalah dengan pembuatan jalur evakuasi. Tujuannya untuk menyiapkan prosedur evakuasi bagi masyarakat di kawasan wisata pantai selatan Malang. Hasil yang dicapau seluruh peserta kegiatan aktif terlibat dalam kegiatan.

Kegiatan pengabdian masyarakat yang dilakukan di desa Sumber Bening, Kecamatan Bantur Kabupaten Malang di awali dengan pengkajian awal. Pengkajian awal dilakukan untuk mengetahui permasalahan yang muncul di masyarakat. Pengkajian awal di dapatkan data di lapangan bahwa desa Sumber Bening merupakan desa yang memiliki potensi wisata cukup baik. Karena wilayahnya di sekitar pantai selatan Malang. Kawasan wisata pantai yang relatif baru menyebabkan peningkatkan jumlah wisatawan di kawasan tersebut. Namun perlu di perhatikan juga bahwa wisata pantai tentu mempunyai resiko terjadinya suatu bencana seperti tsunami, gempa bumi maupun longsor. Potensi bahaya tidak hanya berdampak pada masyarakat sekitar saja melainkan juga pengunjung wisata. Ancaman bencana tersebut perlu disadari masyarakat setempat sehingga pengunjung wisata merasa aman berwisata di wilayah tersebut.

Seperti diketahui melalui profil desa Sumber Bening bahwa angka kemiskinan di wilayah desa tersebut masih tinggi. Sedangkan kemiskinan menjadi salah satu faktor utama tingkat pengetahuan dan kesadaran masyarakat. Oleh sebab itu perlu adaya upaya untuk meningkatkan kesadaran masyarakat terhadap potensi bencana yang dapat terjadi. Upaya yang dilakukan adalah dengan memberikan penyuluhan dan praktik jalur evakuasi bagi kader di desa Sumber Bening. Kegiatan pengabdian masyarakat yang sudah dilakukan 
STIKES Panti Waluya Malang antara lain memberikan pendidikan mengenai potensi bencana di sekitar pantai, penyuluhan mengenai prosedur evakuasi saat bencana, memberikan pendidikan kegawatdaruratan berupa bantuan hidup dasar, dan pembuatan jalur evakuasi.

\section{KESIMPULAN DAN SARAN}

Pelaksanaan kegiatan pengabdian masyarakat dapat disumpulkan berjalan dengan baik, lancer dan berhasil. Tingkat antusiasme peserta yaitu kader sangat tinggi dilihat dari kehadiran kegiatan yang mencapai $100 \%$ dan terealisasinya seluruh kegiatan yang sudah direncanakan dengan baik. Hal lain yang dapat dijadikan dasar keberhasilan kegiatan adalah adanya peningkatan kesadaran peserta terhadap potensi bencana dan prosedur evakuasi bencana.

Berdasarkan hasil kegiatan yang sudah dilakukan maka pelaksanaan kegiatan mitigasi bencana perlu dilakukan secara periodik dan dilakukan penyegaran sehingga ketangguhan masyarakat terhadap potensi bencana yang dapat semakin meningkat.

\section{DAFTAR PUSTAKA}

Dariyo, A. (2004). Pengetahuan tentang penelitian dan motivasi belajar pada mahasiswa. Jurnal Psikologi, 2(1), 45.

Holly, D., Swanson, V., Cachia, P., Beasant, B., \& Laird, C. (2017). Development of a behaviour rating system for rural/remote pre-hospital settings. Applied Ergonomics, 58, 405-413.

https://doi.org/10.1016/j.apergo.201

6.08.002
Idup, S. T. H., Ilayah, D. I. W., \& Encana, B. E. B. (2004). M Anajemen B Encana : 1-3.

Jokowinarno, D. (2011). Mitigasi Bencana Tsunami Di Wilayah Pesisir Lampung. Jurnal Rekayasa, 15(1), 13-20.

Provinsi Jawa Timur. (2018). Profil kesehatan jawa timur. jakarta: kementria kesehatan republik indonesia.

Sunarto, Marfai, M. A., \& Mardiatno, D. (2014). Penaksiran Multirisiko Bencana di Wilayah Kepesisiran Parangtritis. Yogyakarta: Gajahmada University Press. 